\title{
INTRODUÇÃO À RETÓRICA
}

\author{
Paulo Roberto Gonçalves Segundo*
}

REBOUL, Olivier (2004) Introdução à Retórica. 2.ed. São Paulo: Martins Fontes. (1. ed. 1998).

A obra Introdução à Retórica, de Olivier Reboul, constitui-se em uma das mais importantes publicações sobre Retórica e argumentação na atualidade. Apresentando os estudos retóricos em perspectiva história e as diversas concepções que ela assume no decorrer da evolução do pensamento filosófico e discursivo desde a Grécia Antiga até o mundo ocidental contemporâneo, além de uma síntese profícua acerca das figuras retóricas e dos tipos de argumento, o livro destaca-se pela profundidade e didatismo, sendo uma leitura imprescindível para pessoas da área de Letras, Comunicação, Direito e Filosofia.

A obra pode ser concebida a partir de três grandes eixos: a organização do sistema retórico e sua evolução histórica; a natureza da Retórica; e os recursos retóricoargumentativos - figuras e tipo de argumento - atualizados durante a produção de um texto.

A introdução abarcará a natureza da Retórica. É interessante notar o posicionamento do autor no que se refere a certas posições sobre o assunto, que se diferenciam, em alguns casos, das posições perelmanianas clássicas, presentes no Tratado de Argumentação, como na inaplicabilidade da distinção entre persuadir e convencer, tida por Reboul como incoerente, tendo em vista que o objetivo da persuasão retórica é levar a crer. Levar a fazer torna-se uma conseqüência subsidiária, não necessária. Ademais, argumenta que levar a fazer sem levar a crer implica violência e, desse modo, escapa ao domínio da Retórica. Assim, a distinção dos termos neste domínio torna-se, em seu ponto de vista, impraticável.

O autor define Retórica como a 'arte de persuadir pelo discurso', atribuindo-lhe quatro funções fundamentais — persuasiva, hermenêutica, heurística e pedagógica —, a partir das quais organizará os capítulos seguintes, procurando mostrar, historicamente, de que forma a sociedade conceberá esta arte e sua estruturação, tendo em vista tais eixos condutores.

Assim, os primeiros três capítulos tratam das concepções clássicas da Retórica. Reboul expõe a origem judiciária dessa arte e o pensamento de autores gregos e romanos sobre ela, destacando o papel de relevância que lhe é atribuído por Aristóteles e sua relação com a dialética. Trata-se de importante síntese do pensamento aristotélico, que constitui a base dos estudos em argumentação até a atualidade.

\footnotetext{
Mestrando em Filologia e Língua Portuguesa pela Faculdade de Filosofia, Letras e Ciências Humanas da Universidade de São Paulo.
} 
É somente no terceiro capítulo, no entanto, que ele apresentará as partes componentes do sistema retórico - invenção, disposição, elocução, ação (e a memória, acrescentada pelos romanos) - os gêneros retóricos clássicos - o deliberativo, $\mathrm{o}$ judiciário e o epidíctico - além dos conceitos de ethos, pathos e logos, caros aos estudos na área. Cabe ressaltar o trabalho do autor em relacionar esses elementos e mostrar de que modo eles interagem, fazendo inclusive menções a sua aplicabilidade nos gêneros discursivos atuais.

O quarto capítulo constitui uma transição para a parte seguinte, que aborda os recursos argumentativos propriamente ditos. Neste capítulo, o autor apresenta as possíveis razões do declínio da Retórica, procurando desmistificar a idéia de que o cristianismo teria se configurado como um dos responsáveis pelo declínio dessa arte. Reboul argumenta que a Igreja, por seu papel missionário, necessitava dos recursos retóricos, que foram, inclusive, incorporados na absorção e reformatação do sistema cultural greco-romano pelo cristianismo. Além disso, a Bíblia constituía-se em um amplo modelo e problema retórico, já que ela, tendo em vista seu caráter alegórico, deveria ser interpretada e explicada a partir de procedimentos retóricos. Assim, não há razão, na visão do autor, em se atribuir a uma instituição retórica por excelência o declínio desta atividade, responsabilidade que ele atribui, sim, a Descartes, aos empiristas ingleses, como Locke, ao positivismo e ao romantismo, por razões distintas em cada caso.

$\mathrm{Na}$ sequiência deste mesmo capítulo, o autor apresenta as perspectivas atuais acerca da Retórica, expondo as posições dos principais estudiosos do assunto e suas produções relevantes, como o grupo de Barthes, Genette e Cohen e a obra de Perelman e OlbrechtsTyteca, a qual ele reconhece a grandiosidade, mas critica seu foco exacerbado na invenção. Além disso, Reboul mostra a relação entre Retórica e a publicidade e a comunicação de massa, defendendo que elas tendem a privilegiar o ethos e, principalmente, o pathos, em detrimento do logos na atualidade.

O quinto capítulo introduz o exame dos mecanismos inerentes à Retórica, intercalados por capítulos de aplicação e análise de textos à luz dos elementos expostos nos capítulos precedentes. Nesse sentido, a obra possui um caráter didático relevante, tendo em vista que o autor analisa textos atuais, de diversos gêneros, mostrando a atualidade e a pertinência dos estudos retóricos, muitas vezes, negligenciados por pesquisadores de texto e discurso.

Pontua as cinco características que diferenciam fundamentalmente a demonstração da argumentação:

1. nesta, o discurso sempre se dirige a um auditório, que, para Reboul, é sempre particular, de modo que o auditório universal se constitui apenas em uma pretensão, abstração ou ideal argumentativo;

2. além disso, a argumentação expressa-se em língua natural, sofrendo as conseqüências de sua opacidade;

3. por trabalhar com o verossímil, as premissas argumentativas nunca são verdades propriamente ditas, o que demanda uma relação interpessoal de confiança, atenção e reconhecimento de autoridade da parte do auditório em relação ao orador;

4. nesse sentido, a progressão dos argumentos depende do orador, que procurará ordená-los de modo a satisfazer as condições de persuasão projetadas por ele acerca daquele auditório;

5. por conseguinte, as conclusões tornam-se sempre contestáveis, já que o auditório pode rejeitá-las ou aceitá-las mediante seu julgamento. Consequentemente, não cabe na 
argumentação isolar razão e emoção. As duas caminham necessariamente juntas, na medida em que crenças são intrinsecamente afetivas e afetarão o julgamento e a conclusão, independente do caminho racional da disposição argumentativa apresentada. ${ }^{1}$

O sexto capítulo apresenta uma síntese consistente e bem exemplificada acerca das figuras de retórica. Defende que uma figura é retórica apenas quando serve a fins persuasivos, concebendo-a como derivada do pathos e integrante da elocução.

$\mathrm{O}$ autor arrola uma série de figuras, definindo-as e exemplificando seu funcionamento do ponto de vista persuasivo. Assim, seu papel ornamental é relegado a segundo plano ou mesmo desconsiderado das análises. São subdivididas em figuras de palavras, de sentido, de construção e de pensamento, com subdivisões internas que permitem ao analista depreender as inúmeras estratégias formais relacionadas à textualização dos argumentos, que são aplicadas no sétimo capítulo em análises de textos de gêneros diversos, mostrando a importância de tais elementos no processo persuasivo que lhes é inerente.

Por fim, os capítulos oitavo e nono apresentam, respectivamente, uma tipologia de argumentos e a aplicação de tal tipologia na análise de textos. $\mathrm{O}$ autor definirá quatro grandes tipos de argumento e reduzirá os lugares perelmanianos, que embasam as escolhas individuais, a três: lugar da quantidade, da qualidade e da unidade, mencionando que os outros lugares postulados no Tratado de Argumentação são, na verdade, subsidiários dos anteriormente citados.

Sua tipologia de argumentos é semelhante à do Tratado, com apenas algumas alterações de concepção no que se refere à funcionalidade de certos argumentos. À semelhança de como procede no capítulo sexto, Reboul define e exemplifica os inúmeros argumentos pertencentes ao grupo dos quase lógicos, dos fundados na estrutura do real, dos que fundamentam a estrutura do real e dos que se apóiam na dissociação de noções. Os exemplos advêm de textos, em geral, modernos, de modo que a compreensão se torna mais simples do que a verificada na leitura do texto perelmaniano.

Desse modo, pode-se afirmar que a Introdução à retórica consiste em um texto de significativa importância no âmbito dos estudos argumentativos, apresentando uma visão consistente não só da invenção, mas também da elocução, embora não possua o nível de aprofundamento filosófico encontrado no Tratado de Argumentação, principalmente no que se refere aos valores que calcam as escolhas individuais. Por outro lado, apresenta um olhar mais atual sobre questões retóricas que envolvem os gêneros situados no fim do século XX, início do XXI, colocando uma luz acerca da aplicação da Nova Retórica na análise de textos hodiernos.

\footnotetext{
1 Tal posicionamento, dentre outros, como o referente à cultura de massa anteriormente exposto, permite entrever a sobredeterminação do pathos em relação aos outros elementos na obra de Reboul, que o privilegia teórica e analiticamente em seus estudos.
} 